Article

\title{
Functional Magnetic Mesoporous Silica Microparticles Capped with an Azo-Derivative: A Promising Colon Drug Delivery Device
}

\author{
Adrián H. Teruel ${ }^{1,2} \mathbb{E}^{D}$, Carmen Coll ${ }^{1,2}$, Ana M. Costero ${ }^{1,2,3} \mathbb{C D}^{\text {, Daniel Ferri }}{ }^{1,3}$,

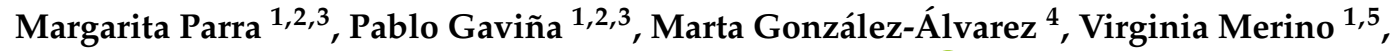 \\ M. Dolores Marcos 1,2,6,7, Ramón Martínez-Máñez 1,2,6,7,* (iD) and Félix Sancenón 1,2,6,7 \\ 1 Interuniversity Research Institute for Molecular Recognition and Technological Development (IDM), \\ Polytechnic University of Valencia, University of Valencia, 46100 Valencia, Spain; adherte@upv.es (A.H.T.); \\ macolme1@upvnet.upv.es (C.C.); ana.costero@uv.es (A.M.C.); daniel.ferri@uv.es (D.F.); \\ margarita.parra@uv.es (M.P.); pablo.gavina@uv.es (P.G.); Virginia.merino@uv.es (V.M.); \\ mmarcos@qim.upv.es (M.D.M.); fsanceno@upvnet.upv.es (F.S.) \\ CIBER of Bioengineering, Biomaterials and Nanomedicine (CIBER-BBN), 28029 Madrid, Spain \\ Department of Organic Chemistry, University of Valencia, 46100 Valencia, Spain \\ 4 Engineering Department. Pharmacy and Pharmaceutical Technology Section, Miguel Hernandez University, \\ 03550 Alicante, Spain; marta.gonzalez@umh.es \\ 5 Pharmacy and Pharmaceutical Technology and Parasitology, University of Valencia, 46100 Valencia, Spain \\ 6 Joint Research Unit in Nanomedicine and Sensors. Polytechnic University of Valencia, Health Research \\ Institute Hospital La Fe, 46100 Valencia, Spain. \\ 7 Joint Unit CIPF-UPV of Mechanisms of Diseases and Nanomedicine, Valencia, Polytechnic University of \\ Valencia, Prince Felipe Research Center, 46100 Valencia, Spain \\ * Correspondence: rmaez@qim.upv.es; Tel.: +34-963-877-343
}

Received: 15 January 2018; Accepted: 8 February 2018; Published: 10 February 2018

\begin{abstract}
Magnetic micro-sized mesoporous silica particles were used for the preparation of a gated material able to release an entrapped cargo in the presence of an azo-reducing agent and, to some extent, at acidic $\mathrm{pH}$. The magnetic mesoporous microparticles were loaded with safranin $\mathrm{O}$ and the external surface was functionalized with an azo derivative $\mathbf{1}$ (bearing a carbamate linkage) yielding solid S1. Aqueous suspensions of S1 at pH 7.4 showed negligible safranin O release due to the presence of the bulky azo derivative attached onto the external surface of the inorganic scaffold. However, in the presence of sodium dithionite (azoreductive agent), a remarkable safranin O delivery was observed. At acidic $\mathrm{pH}$, a certain safranin $\mathrm{O}$ release from $\mathbf{S 1}$ was also found. The $\mathrm{pH}$-triggered safranin $O$ delivery was ascribed to the acid-induced hydrolysis of the carbamate moiety that linked the bulky azo derivatives onto the mesoporous inorganic magnetic support. The controlled release behavior of $\mathbf{S} \mathbf{1}$ was also tested using a model that simulated the gastro intestinal tract.
\end{abstract}

Keywords: magnetic mesoporous silica; azo derivatives; $\mathrm{pH}$ triggered; azo reductor; colon release

\section{Introduction}

In recent years, the blending of coordination, molecular, supramolecular and biomolecular chemistry concepts with porous materials has led to the development of smart functional gated materials with multiple applications in different scientific and technological fields [1]. These hybrid materials are mainly composed by two subunits: (i) an inorganic porous support for cargo loading; and (ii) certain molecules acting as "molecular gates" for controlled cargo release upon the application of external stimuli [2]. 
One of the most commonly used inorganic supports in gated materials is mesoporous silica due to its outstanding features such as biocompatibility, inertness and chemical stability, high loading capacity and ease of functionalization using the well-known alkoxysilane chemistries [3]. Besides, mesoporous silica can be prepared as micro- or nanoparticles, the diameter of the pores can also be adjusted from the typical 2-3 nm range to ca. 6-10 $\mathrm{nm}$ (to include inside the porous network biomolecules such as small peptides, DNA fragments or enzymes) and can be prepared including other nanoparticles (for example, magnetite) in their structure endowing the final support with novel features [4-6].

These "gated materials" have been extensively used in controlled release processes [7-10] as well as in sensing/recognition protocols (when a dye or fluorophore is released in the presence of a target molecule) [11] and, very recently, in abiotic communication networks involving several gated nanodevices $[12,13]$. Dealing with controlled drug release, the preparation of carriers able to deliver certain drugs at-will and on the site of action, minimizing secondary effects, is a benchmark in the treatment of different diseases [14].

From another point of view, colon drug delivery systems (CDDS) have been developed for their use in two main applications: (i) to deliver macromolecular drugs, such as protein or peptides that found in the colon a better environment to be absorbed without losing activity because of the relatively low proteolytic enzyme activity and good absorption (e.g., insulin, calcitonin, and vasopressin); and (ii) to increase the efficacy in prevention and treatment of colon related diseases (e.g., irritable bowel syndrome, inflammatory bowel diseases (IBD), and colorectal cancer) $[15,16]$. In fact, the development of CDDS is an excellent strategy to deliver certain drugs in colon, decreasing adverse effects and enhance drug efficacy. With this aim, smart formulations for targeting colon such as $\mathrm{pH}$-responsive biodegradable polymers, time-dependent formulations, pressure responsive systems, osmotic controlled materials, bio-adhesive systems, enzyme triggered prodrugs or drugs coated with enzyme-sensitive polymers have been recently developed [17-19].

Despite these examples, the use of hybrid organic-inorganic gated materials based on mesoporous silica for the development of CDDS is still an almost unexplored field. For the preparation of these CDDS silica-based nanodevices, enzymes produced by colon microbiota (azoreductase, $\beta$-galactosidase, $\beta$-xylosidase, nitroreductase, glycosidase deaminase, etc.) are ideal candidates to be used as external triggers [20,21].

Bearing in mind our interest in the development of silica-based gated materials for controlled release applications [22-29], we report herein the preparation of capped a micro-sized silica mesoporous solid containing magnetic nanoparticles (S1) as a suitable carrier to release an entrapped cargo in colon. Although not specifically tested in this present work, the magnetic character of the prepared nanodevice may be useful to enhance the retention time of the particles in the part of interest of the intestinal tract (for instance in colon). Moreover, particles $\mathbf{S} \mathbf{1}$ are loaded with a dye and capped with an azoderivative attached to the external surface of the inorganic matrix by means of a carbamate group. We demonstrated that the presence of the bulky azoderivative onto the external surface of $\mathbf{S 1}$ inhibited cargo release, whereas in the presence of a reducing agent delivery was observed. The solid was also able to deliver the cargo to some extent at acidic $\mathrm{pH}$. A study on payload release from $\mathbf{S 1}$ in a simulated digestive process in mouth, stomach, small intestine and colon is also reported.

\section{Results and Discussion}

\subsection{Synthesis of Gated Magnetic Micro-Sized Mesoporous Silica Particles}

Magnetic nanoparticles (MNPs) coated with oleic acid were prepared by a co-precipitation procedure that used a mixture of $\mathrm{FeCl}_{3}$ and $\mathrm{FeCl}_{2}$ and ammonium hydroxide [30]. Moreover, mesoporous silica was prepared following the "atrane route" with small modifications [31,32]. In this synthetic protocol, $n$-cetyltrimethylammonium bromide was used as structural directing agent and tetraethylortosilicate as silica source. MNPs were suspended in water and incorporated into the synthesis crude before the addition of $\mathrm{NaOH}$. The resulting brownish powder was washed and the 
surfactant was subsequently removed by calcination. This procedure yielded the final magnetic micro-sized inorganic solid (S0). Once the magnetic mesoporous support was synthesized, the pores of the siliceous phase were loaded with safranin $\mathrm{O}$ (as a model drug in our study) and the external surface functionalized with the bulky azo-containing derivative 1. This synthetic protocol yielded micro-sized magnetic solids S1 (see Scheme 1). It was expected that the bulky azo-containing derivative 1 would inhibit dye leaching from the pores, whereas safranin $\mathrm{O}$ delivery should be observed in the presence of sodium dithionite (able to hydrolyze azo linkages) or partially at acidic $\mathrm{pH}$ (due to the hydrolysis of the carbamate moiety in $\mathbf{1}$ ).

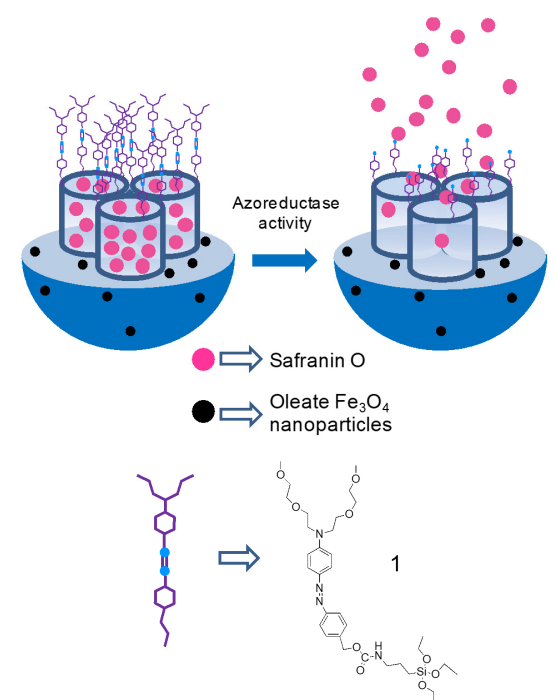

Scheme 1. Magnetic micrometric silica mesoporous supports loaded with safranin $\mathrm{O}$ and capped with azo derivative (1). Safranin $\mathrm{O}$ is released in the presence of an azoreductor.

The synthesis of azo-containing alkoxysilane derivative $\mathbf{1}$ (see Scheme 2 ) starts with the mesylation of 2-methoxyethanol (1a) in dichloromethane that yielded $\mathbf{1 b}$ [33]. Then, in a second step, $\mathbf{1 b}$ was reacted with the disodium salt of $N$-phenyldiethanolamine (1c) obtaining the oligoethylenglycol derivative 1d. Afterwards, 1d was reacted with the diazonium salt of 4-aminobenzyl alcohol (1e) yielding azo derivative 1f. Finally, azo-containing trialkoxysilane derivative $\mathbf{1}$ was obtained upon reaction between $\mathbf{1 f}$ and (3-isocyanatopropyl) triethoxysilane (1g). The final azo-containing trilakoxysilane derivative (1) was fully characterized using ${ }^{1} \mathrm{H}$ - and ${ }^{13} \mathrm{C}-\mathrm{NMR}$ and HRMS.

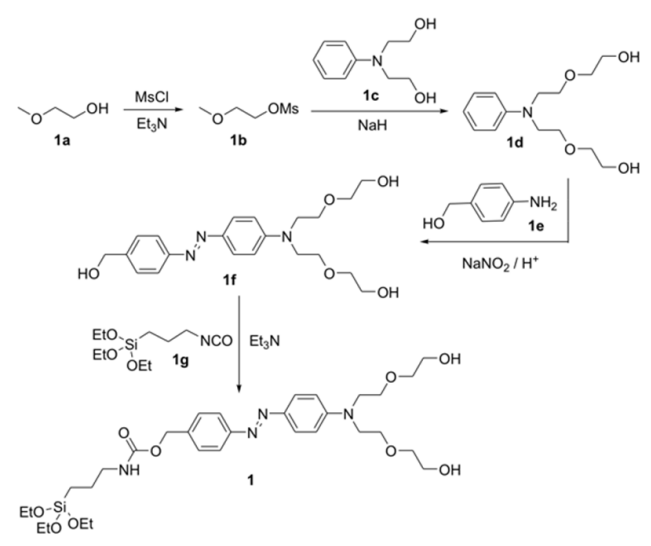

Scheme 2. Synthetic route used for the preparation of azoderivative 1. 2-methoxyethanol (1a); 2-methoxyethyl methanesulfonate (1b); $N$-phenyldiethanolamine (1c); oligoethylenglycol derivative (1d); 4-aminobenzyl alcohol (1e); azo derivative (1f); (3-isocyanatopropyl) triethoxysilane (1g). 


\subsection{Characterization of the Prepared Materials}

S0 and S1 were characterized using powder X-ray diffraction (PXRD), transmission electron microscopy (TEM), scanning transmission electron microscopy (STEM), $\mathrm{N}_{2}$ adsorption-desorption isotherms and thermogravimetric analysis. Figure 1 shows the PXRD patterns (at high and low angles) of oleate-stabilized MNPs, the magnetic mesoporous microparticles as-made, S0 and S1. PXRD of oleate-coated MNPs (see also Figure 1) showed the five typical high-angle reflections of magnetite phase indexed as (220), (311), (400), (511) and (440) Bragg peaks. The same peaks were observed for the as-made microparticles, $\mathbf{S 0}$ and $\mathbf{S 1}$ materials but with a marked decrease in intensity (Figure 1). This intensity loss was ascribed to the inclusion of MNPs into the inorganic mesoporous matrix. Low angle PXRD pattern of as-made microparticles (Figure 1) displayed the typical reflections of a hexagonal-ordered mesoporous system that can be indexed as (100), (110), (200) and (210) Bragg peaks. A shift of the (100) peak in calcined S0 solid was clearly observed. This displacement is consistent with an approximate cell contraction of $3.64 \AA$ and is attributed to the condensation of silanol groups during the calcination step. The presence of the characteristic (100) reflection in the diffraction spectrum of S1 clearly indicated that the mesoporous structure was preserved throughout the filling process with safranin $\mathrm{O}$ and the anchoring of the azo derivative 1.

a)

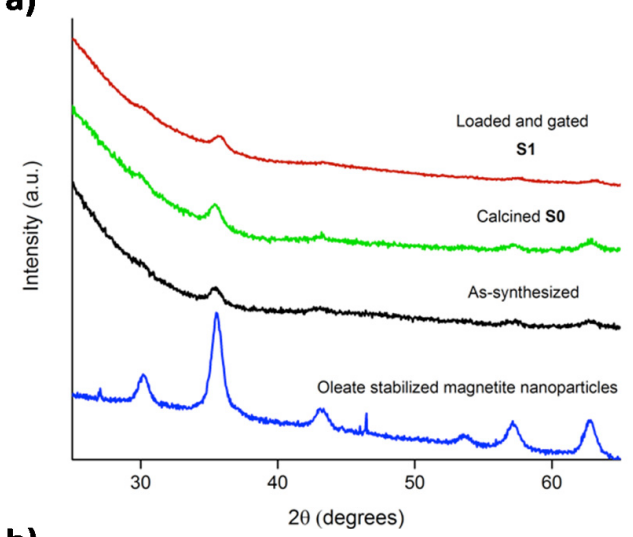

b)

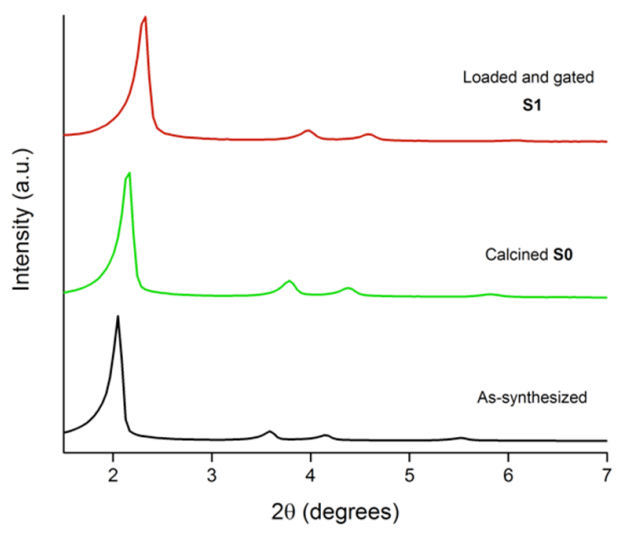

Figure 1. Powder $X$-rays patterns at: (a) high angles; and (b) low angles of oleate stabilized magnetite $\left(\mathrm{Fe}_{3} \mathrm{O}_{4}\right)$ nanoparticles and magnetic micrometric mesoporous silica particles as-synthesized, S0 and S1.

Figure 2 shows transmission electron microscopy (TEM) images of solid S0. As could be seen, the typical porosity associated with the mesoporous inorganic support was present. Besides, MNPs were observed as small dark dots. Scanning transmission electron microscopy (STEM) images of solid S0 (iron mapping) indicated that MNPs are randomly distributed through the mesoporous silica microparticles (Figure 3). Moreover, to assess the magnetic behavior of S0, field 
dependent magnetization curves measured at $298 \mathrm{~K}$ were obtained. The obtained curves (see Figure 4) displayed no hysteresis loops and showed coercivity values near zero, in agreement with a typical superparamagnetic behavior at room temperature. The saturation magnetization value for S0 was $1.5 \mathrm{emu} / \mathrm{g}$. This magnetization value is not far from those reported in the literature for other magnetic mesoporous silica particles, which are typically in the 1.7-10 emu/g range [30].

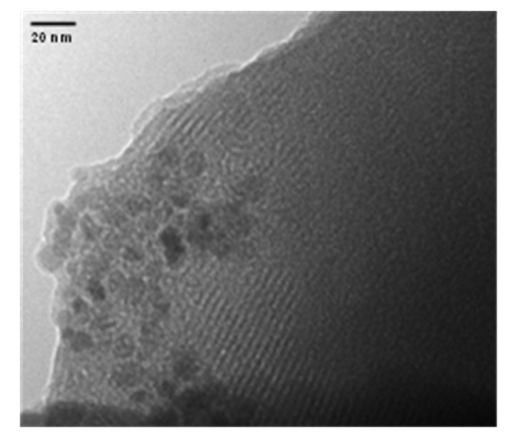

Figure 2. TEM image of micrometric mesoporous silica particles containing magnetite nanoparticles (S0).
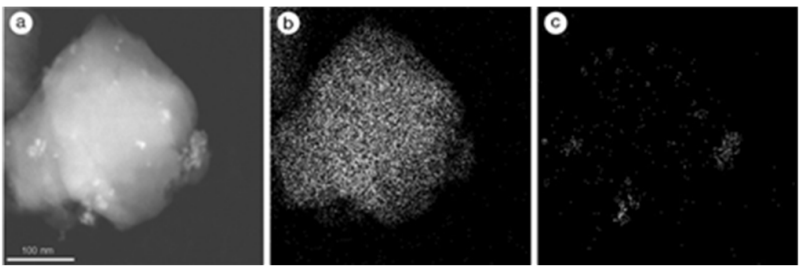

Figure 3. (a) STEM images of micrometric mesoporous silica particles containing magnetite nanoparticles (S0); (b) silica mapping; and (c) iron mapping.

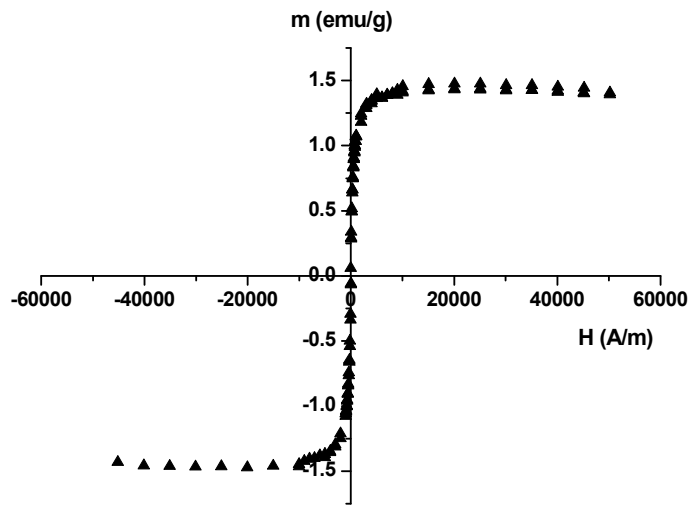

Figure 4. Field-dependent magnetization curves at room temperature of S0 microparticles.

$\mathrm{N}_{2}$ adsorption-desorption studies of $\mathbf{S} 0$ and $\mathbf{S} 1$ were also carried out (Figure 5). As could be seen, solid S0 showed a typical curve for mesoporous silica materials, with an adsorption step at intermediate $\mathrm{P} / \mathrm{P}_{0}$ values (0.2-0.4). This isotherm is classified as type IV in which the absorption step deals with nitrogen condensation inside the mesopores. The pore diameter of S0 was calculated by the Barret-Joyner-Halenda (BJH) method [34]. The narrow BJH pore distribution observed and the absence of a hysteresis loop in the $0.2-0.4 \mathrm{P} / \mathrm{P}_{0}$ interval suggested the existence of uniform cylindrical mesopores. Values of pore diameter of $2.83 \mathrm{~nm}$ and pore volume of $0.94 \mathrm{~cm}^{3} \mathrm{~g}^{-1}$, calculated on the adsorption branch of the isotherm, were found. Pore diameter estimated from TEM images agree with this value. The application of the Brunauer-Emmett-Teller (BET) model [35] gave a value of $1057 \mathrm{~m}^{2} \mathrm{~g}^{-1}$ for the total specific surface. On the other hand, the $\mathrm{N}_{2}$ adsorption-desorption isotherms 
of solid S1 are typical of mesoporous systems with partially filled mesopores, and a decrease in both the adsorbed $\mathrm{N}_{2}$ volume and the specific surface area was clearly observed (Table 1). This reduction in the BET surface, compared with that of S0, was ascribed to the loading of pores with safranin $\mathrm{O}$ and the functionalization of the surface with the bulky azo derivative $\mathbf{1}$ in S1.

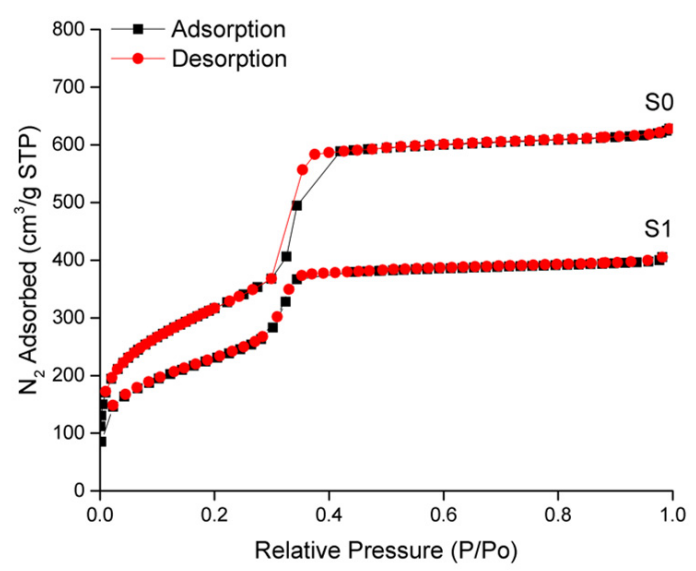

Figure 5. $\mathrm{N}_{2}$ adsorption-desorption isotherms for $\mathbf{S} 0$ and $\mathbf{S 1}$ materials.

Table 1. BET specific surface values, pore volumes and pore sizes for S0 and S1.

\begin{tabular}{cccc}
\hline Solid & $\mathrm{S}_{\text {BET }}\left(\mathbf{m}^{\mathbf{2}} \mathbf{g}^{-\mathbf{1}}\right)$ & pore volume $^{\mathbf{1}}\left(\mathbf{c m}^{\mathbf{3}} \mathbf{g}^{-\mathbf{1}}\right)$ & pore size $^{\mathbf{1 , 2}}(\mathbf{n m})$ \\
\hline S0 & 1057 & 0.94 & 2.83 \\
S1 & 834 & 0.68 & -
\end{tabular}

${ }^{1}$ Total pore volume according to the BJH model. ${ }^{2}$ Pore size estimated by using the BJH model applied on the adsorption branch of the isotherm, for $\mathrm{P} / \mathrm{P}_{0}<0.6$, which can be associated to the surfactant generated mesopores.

Total organic matter on solid S1 was determined by thermogravimetric analysis (see Supplementary Materials) and ${ }^{1} \mathrm{H}-\mathrm{NMR}$ (Table 2). The amount of anchored azo derivative onto S1 was determined by ${ }^{1} \mathrm{H}-\mathrm{NMR}$ upon dissolving the corresponding sample in $\mathrm{HF} / \mathrm{D}_{2} \mathrm{O}$ in the presence of tetraethyl ammonium bromide as internal standard (Table 2) [36]. Besides, energy dispersive X-ray spectroscopy (EDX, $20 \mathrm{kV}$ ) was used to determine Si and Fe content in S1 microparticles. EDX measurements showed a value of 5.9 for the $\mathrm{Si} / \mathrm{Fe}$ ratio in the final $\mathbf{S 1}$ solid.

Table 2. Content of total organic matter (in g) per gram of $\mathrm{SiO}_{2}$, content of azo derivative (in g) per gram of $\mathrm{SiO}_{2}$ and dye released (in $\mu \mathrm{g}$ ) per mg of solid in $\mathbf{S 1}$.

\begin{tabular}{cccc}
\hline Solid & Organic Content $\left(\mathrm{g} / \mathrm{g} \mathrm{SiO}_{2}\right)$ & Azo Derivative $\left(\mathrm{g} / \mathrm{g} \mathrm{SiO}_{2}\right)$ & Dye Release $(\mu \mathrm{g} / \mathrm{mg}$ solid) \\
\hline $\mathrm{S} 1$ & 0.0469 & 0.043 & 0.69 \\
\hline
\end{tabular}

\subsection{Cargo Release from $\mathbf{S 1}$}

Payload release from solid S1 at acidic (2.0 and 4.5) and neutral (7.4) pH in the presence or absence of the azoreductor agent sodium dithionite was studied $[37,38]$. These $\mathrm{pH}$ values were selected taking into account the possible use of $\mathbf{S 1}$ as nanodevice for controlled release in colon: $\mathrm{pH} 2.0$ is typical of gastric juices, $\mathrm{pH} 4.5$ is found in the transition from stomach to intestines (this $\mathrm{pH}$ can also be found in the colon of IBD patients), and a neutral $\mathrm{pH}$ ranging 6.5-7.4 is typically found in the intestine. In a typical experiment, $2 \mathrm{mg}$ of $\mathbf{S 1}$ were suspended in water at selected $\mathrm{pH}$ values, the final suspensions stirred at $37.5^{\circ} \mathrm{C}$ and aliquots were taken at scheduled times. The aliquots were centrifuged to remove the solid and the release of safranin $\mathrm{O}$ to the solution monitored by measuring fluorescence at $571 \mathrm{~nm}$ upon excitation at $520 \mathrm{~nm}$. Cargo release profile for solid S1 is shown in Figure 6. Aqueous suspensions 
of $\mathbf{S 1}$ showed negligible safranin $\mathrm{O}$ release at neutral $\mathrm{pH}$. However, as a clear contrast, a marked delivery of entrapped safranin $\mathrm{O}$ was seen in the presence of sodium dithionite (more than $80 \%$ of maximum dye delivered after $4 \mathrm{~h}$ ). The observed delivery is attributed to the presence of sodium dithionite, which can reduce azo groups in the capping molecule 1 resulting in pore opening and safranin $\mathrm{O}$ release [37,38]. At acidic $\mathrm{pH}$ (2.0 and 4.5), a sustained safranin O release was also observed. Delivery of entrapped safranin $\mathrm{O}$ was ascribed to a hydrolysis of carbamate moieties, which linked the bulky azo derivative $\mathbf{1}$ onto the external surface of $\mathbf{S 1}$. Maximum release of safranin O for S1 was ca. $0.51 \mu \mathrm{g} / \mathrm{mg}$ solid at $\mathrm{pH} 7.4$ in the presence of sodium dithionite.

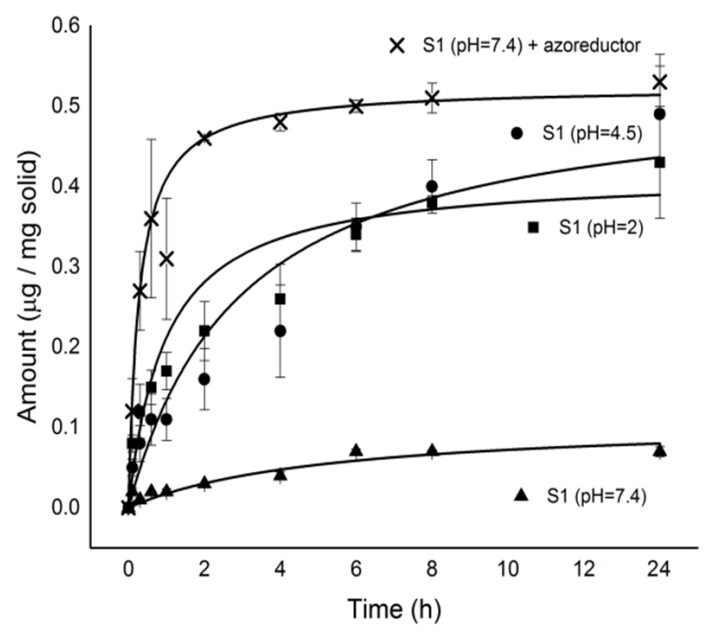

Figure 6. Release kinetics of safranin $\mathrm{O}$ from $\mathrm{S} 1$ in water at $\mathrm{pH} \approx 2$ (square), $\mathrm{pH} \approx 4.5$ (circle), $\mathrm{pH} \approx 7.4$ (triangle) and $\mathrm{pH} \approx 7.4$ in the presence of azoreductor agent sodium dithionite (SD, $57.4 \mathrm{mM})$ (cross).

\subsection{In Vitro Digestion Model Assay}

Despite the partial payload delivery from $\mathbf{S 1}$ at acidic $\mathrm{pH}$ shown above, it has to be noted that permanence of the particles in the stomach is usually less than $2 \mathrm{~h}$ and therefore only a partial cargo delivery from S1 is expected to occur before targeting colonic tissues. In fact, to study in depth the possible application of azo-gated magnetic microparticles as suitable particles for cargo delivery in colon, payload delivery from S1 was further tested in a model of digestion using simulated solutions. The model used was a modification of that introduced by Oomen and co-workers [39,40] that is a three-step procedure simulating digestive process in mouth, stomach and small intestine. Moreover, we introduced a fourth step to simulate the digestive process in colon. In a typical experiment, $2 \mathrm{mg}$ of solid (S1) were suspended in simulated saliva $\left(5 \mathrm{~min}\right.$ at $\left.37.5^{\circ} \mathrm{C}\right)$ and then simulated gastric juice (stomach) was added and the mixture stirred $2 \mathrm{~h}$. Afterwards, duodenal simulated juice, bile and bicarbonate solution (small intestine) were added and the suspension stirred for two more hours. Finally, sodium dithionite was added and it was left for $24 \mathrm{~h}$ to mimic the colon environment and the presence of azoreductases. Safranin O release in the entire process was evaluated via monitorization of the emission at $571 \mathrm{~nm}$ upon excitation at $520 \mathrm{~nm}$. The obtained results are shown in Figure 7.

As shown in Figure 7, a nearly "zero release" was observed during the first 5 min when solids were in contact with simulated saliva. In contact with gastric juice, a safranin O delivery of ca. $0.3 \mu \mathrm{g} / \mathrm{mg}$ solid was found and ascribed to partial pore opening due to the acidic environment. In small intestine conditions, no further delivery of safranin $\mathrm{O}$ was observed. However, a marked cargo release was found in simulated colon conditions and related with the presence of sodium dithionite, which can reduce azo bonds of the capping ensemble in $\mathbf{S 1}$. 


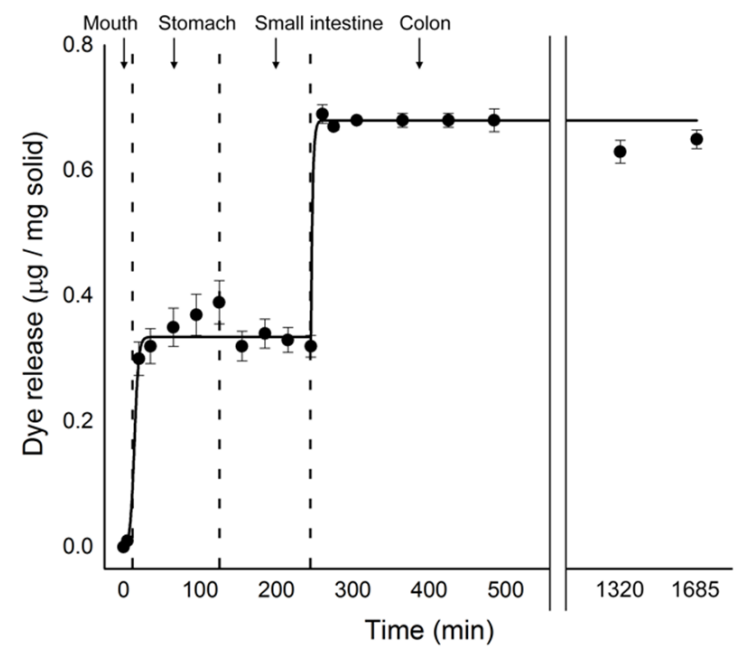

Figure 7. Release kinetics of Safranin O from S1 in simulated gastro-intestinal tract (GIT) fluids.

\section{Materials and Methods}

\subsection{General Techniques}

Transmission electron microscopy (TEM), scanning transmission electron microscope (STEM), powder X-ray diffraction (PXRD), thermogravimetric analysis (TGA), $\mathrm{N}_{2}$ adsorption-desorption, nuclear magnetic resonance (NMR), Fourier transform infrared spectroscopy (FT-IR) and fluorescence spectroscopy techniques were employed to characterize the synthesized materials. TEM and STEM images were acquired using a JEOL JEM-1010 and a JEOL JEM 2100F microscopes (Akishima, Japan), respectively. PXRD measurements were performed on a Bruker D8 Advance diffractometer (Billerica, MA, USA) using $\mathrm{CuK}_{\alpha}$ radiation. TGA were carried out on a TGA/SDTA 851e Mettler Toledo balance (Greifensee, Switzerland), using an oxidant atmosphere (air, $80 \mathrm{~mL} / \mathrm{min}$ ) with a heating program consisting on a heating ramp of $10^{\circ} \mathrm{C}$ per minute from 393 to $1273 \mathrm{~K}$ and an isothermal heating step at this temperature for $30 \mathrm{~min}$. $\mathrm{N}_{2}$ adsorption-desorption isotherms were recorded with a Micromeritics ASAP 2010 automated sorption analyzer (Norcross, GA, USA). The samples were degassed at $120^{\circ} \mathrm{C}$ under vacuum overnight. The specific surface areas were calculated from the adsorption data in the low pressure range using the Brunauer-Emmett-Teller (BET) model. Pore size was determined following the Barrett-Joyner-Halenda $(\mathrm{BJH})$ method. ${ }^{1} \mathrm{H}$ NMR spectra were recorded using a Bruker AV400 spectrometer (Billerica, MA, USA). Infrared spectra were recorded using a Bruker Tensor 27 equipment (Billerica, MA, USA). Fluorescence measurements were carried out in a PerkinElmer EnSpire Multimode Plate Reader (Waltham, MA, USA).

\subsection{Chemicals}

The chemicals tetraethylorthosilicate (TEOS), n-cetyltrimethylammonium bromide (CTABr), sodium hydroxide, triethanolamine $\left(\mathrm{TEAH}_{3}\right)$, (3-isocyanatopropyl) triethoxysilane, iron(III) chloride hexahydrate, iron(II) chloride tetrahydrate, oleic acid, safranin O dye, 2-methoxyethanol, triethylamine, methanesulfonyl chloride, hydrochloric acid, $N$-phenyldiethanolamine, anhydrous acetonitrile, sodium hydride, 4-aminobenzyl alcohol, sodium nitrite, sodium dithionite and all chemicals for the digestive fluids were provided by Sigma-Aldrich (Madrid, Spain). Magnesium sulfate, sodium carbonate, and all the analytical-grade solvents were purchased from Scharlab (Barcelona, Spain). Aluminum oxide was acquired from Merck (Madrid, Spain). All products were used as received. 


\subsection{Synthesis of Oleic Acid-coated Magnetic Nanoparticles (MNPs)}

MNPs were prepared using a modified co-precipitation method. In a typical procedure, $\mathrm{FeCl}_{3} \cdot 6 \mathrm{H}_{2} \mathrm{O}(24.0 \mathrm{~g}, 0.089 \mathrm{~mol})$ and $\mathrm{FeCl}_{2} \cdot 4 \mathrm{H}_{2} \mathrm{O}(9.8 \mathrm{~g}, 0.049 \mathrm{~mol})$ were dissolved in deionized water $(100 \mathrm{~mL})$ under nitrogen atmosphere with vigorous stirring at $80{ }^{\circ} \mathrm{C}$. Then ammonium hydroxide $(50 \mathrm{~mL})$ was added quickly into the solution. The colour of the solution immediately turned black and then oleic acid $(3.8 \mathrm{~g}, 0.013 \mathrm{~mol})$ was added after $30 \mathrm{~min}$. The reaction was kept at $80{ }^{\circ} \mathrm{C}$ for $1.5 \mathrm{~h}$. The final oleic acid-coated MNPs were washed with deionized water until neutral $\mathrm{pH}$. Afterwards, the MNPs were transferred into a chloroform solution (30 $\mathrm{mg} \mathrm{MNPs} / \mathrm{mL} \mathrm{CHCl}_{3}$ ).

\subsection{Synthesis of Mesoporous Silica Microparticles Containing MNPs (S0)}

A chloroform suspension of MNPs $(6 \mathrm{~mL}, 30 \mathrm{mg} \mathrm{MNPs} / \mathrm{mL} \mathrm{CHCl} 3$ ) was mixed with an aqueous solution of $\mathrm{CTABr}(8 \mathrm{~mL}, 10 \mathrm{mg} / \mathrm{mL})$ and the resulting suspension was treated with ultrasounds and heated. Finally, ultrasounds were applied again and the suspension was passed through nylon filters $(0.45 \mu \mathrm{M})$ to ensure MNPs homogeneity. Magnetic micro-sized MCM-41 particles were synthesized following the so-called "atrane route". For this purpose, a solution of $\mathrm{TEAH}_{3}(25.79 \mathrm{~g}, 0.173 \mathrm{~mol})$ and $\mathrm{NaOH}\left(2 \mathrm{~mL}\right.$ of a $6 \mathrm{M}$ solution) was heated to $120^{\circ} \mathrm{C}$ and then cooled down to $70{ }^{\circ} \mathrm{C}$, at this moment TEOS $(11 \mathrm{~mL}, 0.045 \mathrm{~mol})$ was added and the crude reaction was heated up to $120^{\circ} \mathrm{C}$. The crude reaction was left cooling down again and $\mathrm{CTABr}(4.68 \mathrm{~g}, 0.013 \mathrm{~mol})$ was added at $118^{\circ} \mathrm{C}$. Next, water containing MNPs (74 mL of distilled water $+6 \mathrm{~mL}$ of the MNPs CTABr-water suspension) was slowly added with vigorous stirring at $70{ }^{\circ} \mathrm{C}$. Besides, $\mathrm{NaOH}(10 \mathrm{~mL}$ of a $0.1 \mathrm{M}$ solution) was added to obtain a $\mathrm{pH} \approx 10.9$. After a few minutes, a brownish suspension was formed. This mixture was aged in an autoclave at $100{ }^{\circ} \mathrm{C}$ for $24 \mathrm{~h}$. The resulting powder was collected by filtration and washed with water. Finally, the solid was dried at $70{ }^{\circ} \mathrm{C}$. To prepare the final solid (S0), the as-synthesized microparticles were calcined at $550{ }^{\circ} \mathrm{C}$ using oxidant atmosphere for $5 \mathrm{~h}$ to remove the template.

\subsection{Synthesis of $\mathbf{1 b}$}

2-Methoxyethanol (1a, $16 \mathrm{~mL}, 0.2 \mathrm{~mol})$ was dissolved in dichloromethane $(270 \mathrm{~mL})$ in a $2 \mathrm{~L}$ round-bottomed flask. The solution was kept in an ice bath for $15 \mathrm{~min}$, and then triethylamine $(55.2 \mathrm{~mL}, 0.4 \mathrm{~mol})$ was added to the solution. Afterwards, a solution of methanesulfonyl chloride in dichloromethane $(0.32 \mathrm{~mol}$ in $48 \mathrm{~mL})$ was added dropwise for $60 \mathrm{~min}$ to the initial reaction crude. After this addition, reaction was stirred at room temperature for another $90 \mathrm{~min}$ period. Then, the crude was poured onto a water/ice mixture containing concentrated hydrochloric acid $(50 \mathrm{~mL})$, and the organic layer was separated, washed three times with brine and dried with anhydrous $\mathrm{MgSO}_{4}$. Dichloromethane was eliminated in a rotary evaporator to give $\mathbf{1 b}$ as yellow oil $(25.16 \mathrm{~g}, 0.18 \mathrm{~mol}, 91 \%$ yield). Spectroscopic data were coincident with those reported in the literature.

\subsection{Synthesis of $\mathbf{1 d}$}

$\mathrm{N}$-phenyldiethanolamine $(\mathbf{1 c}, 3.90 \mathrm{~g}, 0.021 \mathrm{~mol})$ was dissolved in dry acetonitrile $(70 \mathrm{~mL})$ and then the flask was purged several times with argon to remove oxygen and water. Then, sodium hydride $(1.2 \mathrm{~g}, 0.05 \mathrm{~mol})$ was gradually added at room temperature, after which a white precipitate appeared. On the other hand, $\mathbf{1 b}(6 \mathrm{~g}, 0.043 \mathrm{~mol})$ was dissolved in anhydrous acetonitrile $(30 \mathrm{~mL})$ and then added dropwise to the generated dianionic salt of 1c. After this addition, the crude reaction was heated at reflux for $24 \mathrm{~h}$. Then, the reaction mixture was filtered off and the organic solvent was eliminated using a rotary evaporator, yielding a yellow oil. The product $1 \mathrm{~d}(1.25 \mathrm{~g}, 4 \mathrm{mmol}, 20 \%$ yield $)$ was purified using column chromatography with aluminum oxide and hexane/ethyl acetate $(8: 2 v / v)$ as the eluent. Spectroscopic data were consistent with those reported in the literature. 


\subsection{Synthesis of $\mathbf{1 f}$}

4-aminobenzyl alcohol (1e, $414 \mathrm{mg}, 3.36 \mathrm{mmol})$ was dissolved in hydrochloric acid $(150 \mathrm{~mL}$, $\left.4 \mathrm{~mol} \mathrm{~L}^{-1}\right)$. This solution was slowly added to water $(25 \mathrm{~mL})$ containing sodium nitrite $(232 \mathrm{mg}$, $3.36 \mathrm{mmol}$ ) at $5{ }^{\circ} \mathrm{C}$. The generated diazonium salt of $1 \mathbf{e}$ was immediately added to an aqueous solution containing $1 \mathbf{d}(1 \mathrm{~g}, 3.36 \mathrm{mmol})$. The reaction was allowed to react for $30 \mathrm{~min}$ at $5{ }^{\circ} \mathrm{C}$ and for $30 \mathrm{~min}$ at room temperature. The final dark red crude was neutralized with a saturated sodium carbonate solution and the organic product was extracted with dichloromethane. Organic layers were dried with $\mathrm{MgSO}_{4}$ filtered off and the solvent was eliminated in a rotary evaporator. Product $1 \mathrm{ff}(250 \mathrm{mg}$, $0.58 \mathrm{mmol}, 17 \%$ yield) was isolated as a dark red-orange solid through column chromatography with aluminum oxide and hexane/ethyl acetate $(3: 2 v / v)$ as the eluent. ${ }^{1} \mathrm{H}-\mathrm{NMR}\left(400 \mathrm{MHz}, \mathrm{CDCl}_{3}\right): \delta=7.84$ $(\mathrm{d}, 4 \mathrm{H}), 7.46(\mathrm{~d}, 2 \mathrm{H}), 6.79(\mathrm{~d}, 2 \mathrm{H}), 4.75(\mathrm{~s}, 2 \mathrm{H}), 3.74-3.49(\mathrm{~m}, 16 \mathrm{H}), 3.38 \mathrm{ppm}(\mathrm{s}, 6 \mathrm{H}) ;{ }^{13} \mathrm{C}: \delta=50.2,57.4$, $58.1,67.3,69.7,70.9,110.6,121.2,126.5,127.4,141.1,154.9,156.4$ ppm.

\subsection{Synthesis of $\mathbf{1}$}

In a first step, 1f $(520 \mathrm{mg}, 1.2 \mathrm{mmol})$ was dissolved in chloroform $(20 \mathrm{~mL})$. Then, excess of alkoxysilane derivative $1 \mathrm{~g}(468 \mu \mathrm{L}, 1.8 \mathrm{mmol})$ and triethylamine $(468 \mu \mathrm{L}, 0.003 \mathrm{mmol})$ were added under argon atmosphere. The crude reaction was allowed to react for $72 \mathrm{~h}$ at $60^{\circ} \mathrm{C}$. Afterwards, the solvent was eliminated in a rotary evaporator and the reaction crude was washed 3 times with cold hexane to remove impurities. Compound 1 was isolated as orange oil ( $550 \mathrm{mg}, 0.810 \mathrm{mmol}, 67 \%$ yield). ${ }^{1} \mathrm{H}-\mathrm{NMR}\left(400 \mathrm{MHz}, \mathrm{CDCl}_{3}\right): \delta=7.76(\mathrm{~d}, 4 \mathrm{H}), 7.38(\mathrm{~d}, 2 \mathrm{H}), 6.72(\mathrm{~d}, 2 \mathrm{H}), 5.06(\mathrm{~s}, 2 \mathrm{H}), 4.68(\mathrm{~s}, 1 \mathrm{H}), 3.75$ $(\mathrm{q}, 6 \mathrm{H}), 3.62-3.47(\mathrm{~m}, 16 \mathrm{H}), 3.31(\mathrm{~s}, 6 \mathrm{H}), 3.14(\mathrm{t}, 2 \mathrm{H}), 1.56(\mathrm{~m}, 2 \mathrm{H}), 1.15(\mathrm{t}, 9 \mathrm{H}), 0.56(\mathrm{t}, 2 \mathrm{H}) \mathrm{ppm} ;{ }^{13} \mathrm{C}$ : $\delta=160.9,142.3,139.4,129.9,128.5,127.6,122.4,119.1,114.2,111.8,100.2,72.1,70.8,68.5,65.3,59.2,51.4$, 32.1, 29.9, 29.5, 22.8, 14.3, 1.2 ppm. HRMS-EI $m / z$ : calcd for $\mathrm{C}_{33} \mathrm{H}_{54} \mathrm{~N}_{4} \mathrm{O}_{9} \mathrm{Si} 678.3660$; found: 677.2403 $\left(\mathrm{M}-\mathrm{H}^{+}\right)$.

\subsection{Synthesis of $\mathbf{S 1}$}

Magnetic mesoporous silica microparticles $(\mathbf{S} 0,270 \mathrm{mg}$ ) were suspended in an acetonitrile solution $(10 \mathrm{~mL})$ of safranin $\mathrm{O}(75 \mathrm{mg}, 0.8 \mathrm{mmol} / \mathrm{g} \mathrm{S0})$ under argon atmosphere. The obtained suspension was then stirred at room temperature overnight to achieve maximum loading of the pores. Afterward, $1(550 \mathrm{mg}, 3 \mathrm{mmol} / \mathrm{g} \mathrm{S}$ ) was dissolved in anhydrous acetonitrile $(8 \mathrm{~mL})$ and was added to the microparticle/dye suspension. The mixture was stirred at room temperature for $6 \mathrm{~h}$ in an argon atmosphere. $\mathbf{S 1}$ was isolated by centrifugation, washed several times with acetonitrile and was finally dried at $40{ }^{\circ} \mathrm{C}$ for $24 \mathrm{~h}$.

\subsection{Controlled Release Studies}

Controlled release studies from S1 were tested at different $\mathrm{pH}$ values (i.e., 2.0, 4.5 and 7.4) and in the presence of a reductive environment (sodium dithionite, which is known to reduce azo linkages). In a typical experiment, $2 \mathrm{mg}$ of the corresponding solid were suspended in water at the selected $\mathrm{pH}$ $(2 \mathrm{~mL})$ and aliquots were extracted at given times $(0,5 \mathrm{~min}, 20 \mathrm{~min}, 40 \mathrm{~min}, 1 \mathrm{~h}, 2 \mathrm{~h}, 4 \mathrm{~h}, 6 \mathrm{~h}, 8 \mathrm{~h}$, and $24 \mathrm{~h}$ ), centrifuged to remove the solid and supernatants were loaded into a 96 -well plate to measure safranin O fluorescence at $571 \mathrm{~nm}$ (excitation at $520 \mathrm{~nm}$ ). Controlled release from S1 microparticles were also tested in in vitro digestion conditions using simulated solutions for saliva, gastric juice, duodenal juice and bile $[39,40]$. In vitro digestion experiments were carried out with $\mathbf{S 1}(2 \mathrm{mg})$ at $37^{\circ} \mathrm{C}$ (temperature of the human body) and stirring at 12,000 rpm (to ensure the correct suspension of the microparticles). Digestions started by adding simulated saliva fluid $(320 \mu \mathrm{L})$ and incubating for $5 \mathrm{~min}$. Then, simulated gastric juice $(630 \mu \mathrm{L})$ was added, and the mixture was stirred for $2 \mathrm{~h}$. Later, simulated duodenal juice $(630 \mu \mathrm{L})$, bile $(320 \mu \mathrm{L})$ and a bicarbonate solution $(1 \mathrm{M}, 100 \mu \mathrm{L})$ were added simultaneously and the mixture was stirred for another $2 \mathrm{~h}$. Finally, colon fluid was simulated by adding sodium dithionite $(20 \mathrm{mg}, 57.4 \mathrm{mM} / 2 \mathrm{~mL})$. Aliquots were taken at given times $(0,5,20,35,65$, 
$95,125,155,185,215,245,260,275,305,365,425,485,1320$ and $1685 \mathrm{~min})$, centrifuged and supernatants were loaded into a 96 well plate to measure safranin $\mathrm{O}$ fluorescence. Calibration curves, in water, simulated small intestine fluid and simulated colon fluid, were performed to assess the amounts of safranin $\mathrm{O}$ released from solid $\mathbf{S 1}$ in the different environments.

\section{Conclusions}

As summary, here we have reported the synthesis and characterization of magnetic mesoporous silica microparticles loaded with safranin $\mathrm{O}$ and capped with bulky azo derivative bearing pH-hydrolysable moieties (carbamate group). At neutral $\mathrm{pH}$, the capped material showed a negligible safranin $\mathrm{O}$ release. However, at neutral $\mathrm{pH}$, addition of a reducing agent such as sodium dithionite (mimicking azoreductase enzyme) induced a marked safranin O release. The observed delivery was ascribed to a reduction of the azo bonds that induced a fall in the steric crowding around pore outlets with subsequent dye delivery. Moreover, a partial payload release was also observed at acidic $\mathrm{pH}$. Delivery studies in a digestion model indicated an important part of the payload was released in colon. These particles are expected to find applications as smart controlled drug delivery systems in the colon mucosa (e.g., for IBD patients) due to the presence of azoreductase enzymes produced by bacteria in the colon microbiota. Besides, its ability to release the cargo at acidic $\mathrm{pH}$, opens the possibility to improve the performance of these carriers for drug delivery in ulcerative colitis and Crohn's disease in which a marked decrease in the $\mathrm{pH}$ of the colon happens [41,42]. Moreover, these microparticles (S1) were equipped with magnetic nanoparticles to potentially apply magnetic fields to enhance the retention time of the solids in colon. Similar magnetic microparticles to those reported here and loaded with a drug (e.g., 5-ASA) are promising materials for the oral treatment of colon related diseases. Further in vivo studies in this line will be performed in due course.

Supplementary Materials: The Supplementary Materials are available online.

Acknowledgments: We thank the Spanish Government (projects MAT2015-64139-C4-1-R and AGL2015-70235C2-2-R (MINECO/FEDER)) and the Generalitat Valenciana (project PROMETEOII/2014/047) for support. AHT thanks to the Spanish MEC for his FPU grant. The authors also thank the Electron Microscopy Service at the Universitat Politècnica de València for support. SCSIE (Universitat de València) is also gratefully acknowledged for all the equipment employed. NMR was registered at the U26 facility of ICTS "NANBIOSIS" at the Universitat de València. The authors thanks L. A. Villaescusa for his helpful discussion about the ${ }^{1} \mathrm{H}-\mathrm{NMR}$ analysis of the composition of loaded and functionalized supports.

Author Contributions: Adrian H. Teruel, Ana María Costero, Daniel Ferri, Marta Gonzalez-Alvarez, Virginia Merino and Ramón Martínez-Máñez conceived and designed the experiments; Adrian H. Teruel, Carmen Coll, Daniel Ferri, Margarita Parra and Pablo Gaviña performed the experiments; Adrian H. Teruel, Ana María Costero, Daniel Ferri, Margarita Parra, Pablo Gaviña, Marta Gonzalez-Alvarez, Virginia Merino, M. Dolores Marcos, Ramón Martínez-Máñez and Félix Sancenón analyzed the data; and Adrian H. Teruel, Ana María Costero, Ramón Martínez-Máñez and Félix Sancenón wrote the paper.

Conflicts of Interest: The authors declare no conflict of interest.

\section{References}

1. Descalzo, A.B.; Martínez-Máñez, R.; Sancenón, F.; Hoffmann, K.; Rurack, K. The supramolecular chemistry of organic-inorganic hybrid materials. Angew. Chem. Int. Ed. 2006, 45, 5924. [CrossRef] [PubMed]

2. Giménez, C.; de la Torre, C.; Gorbe, M.; Aznar, E.; Sancenón, F.; Murguía, J.R.; Martínez-Máñez, R.; Marcos, M.D.; Amorós, P. Gated mesoporous silica nanoparticles for the controlled delivery of drugs in cancer cells. Langmuir 2015, 31, 3753. [CrossRef] [PubMed]

3. Stein, A. Advances in microporous and mesoporous solids-Highlights of recent progress. Adv. Mater. 2003, 15, 763. [CrossRef]

4. Mekaru, H.; Lu, J.; Tamanoi, F. Development of mesoporous silica-based nanoparticles with controlled release capability for cancer therapy. Adv. Drug Deliv. Rev. 2015, 95, 40. [CrossRef] [PubMed]

5. Baeza, A.; Vallet-Regí, M. Smart mesoporous silica nanocarriers for antitumoral therapy. Curr. Top. Med. Chem. 2015, 15, 2306. [CrossRef] [PubMed] 
6. Ling, D.; Lee, N.; Hyeon, T. Chemical synthesis and assembly of uniformly sized iron oxide nanoparticles for medical applications. Acc. Chem. Res. 2015, 48, 1276. [CrossRef] [PubMed]

7. Aznar, E.; Oroval, M.; Pascual, L.; Murguía, J.R.; Martínez-Máñez, R.; Sancenón, F. Gated materials for on-command release of guest molecules. Chem. Rev. 2016, 116, 561. [CrossRef] [PubMed]

8. Li, Z.; Barnes, J.C.; Bosoy, A.; Stoddart, J.F.; Zink, J.I. Mesoporous silica nanoparticles in biomedical applications. Chem. Soc. Rev. 2012, 41, 2590. [CrossRef] [PubMed]

9. Doane, T.L.; Burda, C. The unique role of nanoparticles in nanomedicine: imaging, drug delivery and therapy. Chem. Soc. Rev. 2012, 41, 2885. [CrossRef] [PubMed]

10. Llopis-Lorente, A.; Lozano-Torres, B.; Bernardos, A.; Martínez-Máñez, R.; Sancenón, F. Mesoporous silica materials for controlled delivery based on enzymes. J. Mater. Chem. B. 2017, 5, 3069. [CrossRef]

11. Sancenón, F.; Pascual, L.; Oroval, M.; Aznar, E.; Martínez-Máñez, R. Gated silica mesoporous materials in sensing applications. ChemistryOpen 2015, 4, 418. [CrossRef] [PubMed]

12. Giménez, C.; Climent, E.; Aznar, E.; Martánez-Máñez, R.; Sancenón, F.; Marcos, M.D.; Amorós, P.; Rurack, K. Towards chemical communication between gated nanoparticles. Angew. Chem. Int. Ed. 2014, 53, 12629. [CrossRef] [PubMed]

13. Llopis-Lorente, A.; Díez, P.; Sánchez, A.; Marcos, M.D.; Sancenón, F.; Martínez-Ruíz, P.; Villalonga, R.; Martínez-Máñez, R. Interactive models of communication at the nanoscale using nanoparticles that talk to one another. Nat. Commun. 2017, 8, 15511. [CrossRef] [PubMed]

14. Coburn, J.M.; Kaplan, D.L. Engineering biomaterial-drug conjugates for local and sustained chemotherapeutic delivery. Bioconj. Chem. 2015, 26, 1212. [CrossRef] [PubMed]

15. Shah, N.K.; Rane, B.R.; Gujarathi, N.A. Developments in colon specific drug delivery systems-A review. Pharm. Sci. Monit. 2014, 5, 95.

16. Singh, G.; Kumar, D.; Singh, M.; Sharma, D.; Kaur, S. Emerging techniques and challenges in colon drug delivery systems. J. Appl. Pharm. Sci. 2012, 2, 139.

17. Malik, K.; Goswami, L.; Kothiyal, P.; Mukhopadhyay, S. A review on colon targeting drug delivery system: Novel approaches, anatomy and evaluation. Pharma. Innov. J. 2012, 1, 1.

18. Lautenschläger, C.; Schmidt, C.; Fischer, D.; Stallmach, A. Drug delivery strategies in the therapy of inflammatory bowel disease. Adv. Drug Deliv. Rev. 2014, 71, 58. [CrossRef] [PubMed]

19. Hua, S.; Marks, E.; Schneider, J.J.; Keely, S. Advances in oral nano-delivery systems for colon targeted drug delivery in inflammatory bowel disease: Selective targeting to diseased versus healthy tissue. Nanomedicine 2015, 11, 1117. [CrossRef] [PubMed]

20. Sinha, V.R.; Kumria, R. Microbially triggered drug delivery to the colon. Eur. J. Pharm. Sci. 2003, 18, 3. [CrossRef]

21. Rubinstein, A. Microbially controlled drug delivery to the colon. Biopharm. Drug Dispos. 1990, 11, 465. [CrossRef] [PubMed]

22. Oroval, M.; Díez, P.; Aznar, E.; Coll, C.; Marcos, M.D.; Sancenón, F.; Villalonga, R.; Martínez-Máñez, R. Self-regulated glucose-sensitive neoglycoenzyme-capped mesoporous silica nanoparticles for insulin delivery. Chem. Eur. J. 2017, 23, 1353. [CrossRef] [PubMed]

23. García-Fernández, A.; García-Laínez, G.; Ferrándiz, M.L.; Aznar, E.; Sancenón, F.; Alcaraz, M.J.; Murguía, J.R.; Marcos, M.D.; Martínez-Máñez, R.; Costero, A.M.; et al. Targeting inflammasome by the inhibition of caspase-1 activity using capped mesoporous silica nanoparticles. J. Control. Release 2017, 248, 60. [CrossRef] [PubMed]

24. Ultimo, A.; Giménez, C.; Bartovsky, P.; Aznar, E.; Sancenón, F.; Marcos, M.D.; Amorós, P.; Bernardo, A.R.; Martínez-Máñez, R.; Jiménez-Lara, A.M.; et al. Targeting innate immunity with dsRNA-conjugated mesoporous silica nanoparticles promotes antitumor effects on breast cancer cells. Chem. Eur. J. 2016, 22, 1582. [CrossRef] [PubMed]

25. Aznar, E.; Coll, C.; Marcos, M.D.; Martínez-Máñez, R.; Sancenón, F.; Soto, J.; Amorós, P.; Cano, J.; Ruiz, E. Borate-driven gatelike scaffolding using mesoporous materials functionalised with saccharides. Chem. Eur. J. 2009, 15, 6877. [CrossRef] [PubMed]

26. Bringas, E.; Köysüren, O.; Quach, D.V.; Mahmoudi, M.; Aznar, E.; Roehling, J.D.; Marcos, M.D.; Martínez-Máñez, R.; Stroeve, P. Triggered release in lipid bilayer-capped mesoporous silica nanoparticles containing SPION using an alternating magnetic field. Chem. Commun. 2012, 48, 5647. [CrossRef] [PubMed] 
27. Agostini, A.; Mondragón, L.; Bernardos, A.; Martínez-Máñez, R.; Marcos, M.D.; Sancenón, F.; Soto, J.; Costero, A.; Manguan-García, C.; Perona, R.; et al. Targeted cargo delivery in senescent cells using capped mesoporous silica nanoparticles. Angew. Chem. Int. Ed. 2012, 51, 10556. [CrossRef] [PubMed]

28. de la Torre, C.; Casanova, I.; Acosta, G.; Coll, C.; Moreno, M.J.; Albericio, F.; Aznar, E.; Mangues, R.; Royo, M.; Sancenón, F.; et al. Gated mesoporous silica nanoparticles using a double-role circular peptide for the controlled and target-preferential release of doxorubicin in CXCR4-expresing lymphoma cells. Adv. Funct. Mater. 2015, 25, 687. [CrossRef]

29. Polo, L.; Gómez-Cerezo, N.; Aznar, E.; Vivancos, J.L.; Sancenón, F.; Arcos, D.; Vallet-Regí, M.; Martínez-Máñez, R. Molecular gates in mesoporous bioactive glasses for the treatment of bone tumors and infection. Acta Biomater. 2017, 50, 114. [CrossRef] [PubMed]

30. Zhang, J.; Li, X.; Rosenholm, J.M.; Gu, H. Synthesis and characterization of pore size-tunable magnetic mesoporous silica nanoparticles. J. Colloid Interface Sci. 2011, 361, 16. [CrossRef] [PubMed]

31. Kresge, C.T.; Leonowicz, M.E.; Roth, W.J.; Vartuli, J.C.; Beck, J.S. Ordered mesoporous molecular sieves synthesized by a liquid-crystal template mechanism. Nature 1992, 359, 710. [CrossRef]

32. El Haskouri, J.; Cabrera, S.; Caldés, M.; Alamo, J.; Beltrán, A.; Marcos, M.D.; Amorós, P.; Beltrán, D. Ordered mesoporous materials: Composition and topology control through chemistry. Int. J. Inorg. Mater. 2001, 3, 1157. [CrossRef]

33. Mas, N.; Agostini, A.; Mondragón, L.; Bernardos, A.; Sancenón, F.; Marcos, M.D.; Martínez-Máñez, R.; Costero, A.M.; Gil, S.; Merino-Sanjuán, M.; et al. Enzyme-responsive silica mesoporous supports capped with azopyridinium salts for controlled delivery applications. Chem. Eur. J. 2013, 19, 1346. [CrossRef] [PubMed]

34. Barrett, E.P.; Joyner, L.G.; Halenda, P.P. The determination of pore volume and area distributions in porous substances. I. Computations from nitrogen isotherms. J. Am. Chem. Soc. 1951, 73, 373. [CrossRef]

35. Brunauer, S.; Emmett, P.H.; Teller, E. Adsorption of gases in multimolecular layers. J. Am. Chem. Soc. 1938, 60, 309. [CrossRef]

36. Pérez-Esteve, E.; Ruiz-Rico, M.; de la Torre, C.; Villaescusa, L.A.; Sancenón, F.; Marcos, M.D.; Amorós, P.; Martínez-Máñez, R.; Barat, J.M. Encapsulation of folic acid in different silica porous supports: A comparative study. Food Chem. 2016, 196, 66. [CrossRef] [PubMed]

37. Lee, S.H.; Moroz, E.; Castagner, B.; Leroux, J.C. Activatable cell penetrating peptide-peptide nucleic acid conjugate via reduction of azobenzene PEG chains. J. Am. Chem. Soc. 2014, 136, 12868. [CrossRef] [PubMed]

38. Yang, Y.Y.; Grammel, M.; Raghavan, A.S.; Charron, G.; Hang, H.C. Comparative analysis of cleavable azobenzene-based affinity tags for bioorthogonal chemical proteomics. Chem. Biol. 2010, 17, 1212. [CrossRef] [PubMed]

39. Versantvoort, C.H.; Oomen, A.G.; Van de Kamp, E.; Rompelberg, C.J.; Sips, A.J. Applicability of an in vitro digestion model in assessing the bioaccessibility of mycotoxins from food. Food Chem. Toxicol. 2005, 43, 31. [CrossRef] [PubMed]

40. Oomen, A.G.; Rompelberg, C.J.; Bruil, M.A.; Dobbe, C.J.; Pereboom, D.P.; Sips, A.J. Development of an in vitro digestion model for estimating the bioaccessibility of soil contaminants. Arch. Environ. Contam. Toxicol. 2003, 44, 281. [CrossRef] [PubMed]

41. Fallingborg, J.; Christensen, L.A.; Jacobsen, B.A.; Rasmussen, S.N. Very low intraluminal colonic $\mathrm{pH}$ in patients with active ulcerative colitis. Dig. Dis. Sci. 1993, 38, 1989. [CrossRef] [PubMed]

42. Sasaki, Y.; Hada, R.; Nakajima, H.; Fukuda, S.; Munakata, A. Improved localizing method of radiopill in measurement of entire gastrointestinal $\mathrm{pH}$ profiles: Colonic luminal $\mathrm{pH}$ in normal subjects and patients with Crohn's disease. Am. J. Gastroenterol. 1997, 92, 114. [PubMed]

Sample Availability: Samples of the compounds are available from the authors. 